\title{
Tsunami hazard at the Western Mediterranean Spanish coast from seismic sources
}

\author{
J. A. Álvarez-Gómez ${ }^{1}$, Í. Aniel-Quiroga ${ }^{1}$, M. González ${ }^{1}$, and L. Otero ${ }^{2}$ \\ ${ }^{1}$ Instituto de Hidráulica Ambiental "IH Cantabria”, E.T.S.I. de Caminos, Canales y Puertos, Universidad de Cantabria, Avda. \\ de los Castros s/n, 39005 Santander, Spain \\ ${ }^{2}$ Dirección General Marítima, Ministerio de Defensa Nacional, Armada Nacional. Av. El Dorado CAN, Bogotá, Colombia
}

Received: 16 October 2010 - Revised: 15 November 2010 - Accepted: 18 November 2010 - Published: 28 January 2011

\begin{abstract}
Spain represents an important part of the tourism sector in the Western Mediterranean, which has been affected in the past by tsunamis. Although the tsunami risk at the Spanish coasts is not the highest of the Mediterranean, the necessity of tsunami risk mitigation measures should not be neglected. In the Mediterranean area, Spain is exposed to two different tectonic environments with contrasting characteristics. On one hand, the Alboran Basin characterised by transcurrent and transpressive tectonics and, on the other hand, the North Algerian fold and thrust belt, characterised by compressive tectonics. A set of 22 seismic tsunamigenic sources has been used to estimate the tsunami threat over the Spanish Mediterranean coast of the Iberian peninsula and the Balearic Islands. Maximum wave elevation maps and tsunami travel times have been computed by means of numerical modelling and we have obtained estimations of threat levels for each source over the Spanish coast. The sources on the Western edge of North Algeria are the most dangerous, due to their threat to the South-Eastern coast of the Iberian Peninsula and to the Western Balearic Islands. In general, the Northern Algerian sources pose a greater risk to the Spanish coast than the Alboran Sea sources, which only threaten the peninsular coast. In the Iberian Peninsula, the Spanish provinces of Almeria and Murcia are the most exposed, while all the Balearic Islands can be affected by the North Algerian sources with probable severe damage, specially the islands of Ibiza and Minorca. The results obtained in this work are useful to plan future regional and local warning systems, as well as to set the priority areas to conduct research on detailed tsunami risk.
\end{abstract}

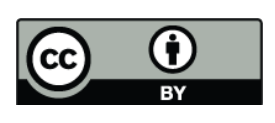

Correspondence to:

J. A. Álvarez-Gómez

(joseantonio.alvarezgomez@unican.es)

\section{Introduction}

The Western Mediterranean is an area of great development in the tourism sector, with increasing population and key to the economy of several countries. Among these Spain represents an important part of the sector supply, being preeminent in the Gibraltar Strait, the Alboran Sea and the Balearic Sea, which are the areas studied in this work. The recent experience of the 2003 Boumerdes-Zemmouri earthquake and tsunami has shown that even moderate events can produce sea waves with enough energy to cause significant economic losses.

In history, tsunamis of varied impact occurred on the Spanish coasts, more destructive on the Atlantic than on the Mediterranean. On the Atlantic coast the tsunamigenic events are produced in the Gulf of Cadiz area, where the 1755 great Lisbon earthquake and tsunami took place. Although the potential to generate destructive events in the Mediterranean area is lower than in the Atlantic, in the past there have been events serious enough to be recorded. In addition to the tsunami of 2003, in 1856 there was another similar event in the Djijelli Area, Northern Algeria, which was recorded in the Balearic Islands. In the Alboran Sea are also known tsunamis that affected the Spanish and African coasts in 1790 (IGN, 2009) and locally in Almeria, in 1804 (IGN, 2009) and perhaps in 1522 (Reicherter and Hübscher, 2007).

Within the area of the North-East Atlantic and Mediterranean, Spain is one of the countries with a higher tsunami risk, not only because of the danger and exposure of their coasts, but also because of its high population density and the importance of tourism infrastructure to the country's economy. Spain is part of the Intergovernmental Coordination Group for the Tsunami Early Warning and Mitigation System in the North-Eastern Atlantic, the Mediterranean and connected seas (ICG/NEAMTWS) from the Intergovernmental Oceanographic Commission of UNESCO (IOC-UNESCO).

Published by Copernicus Publications on behalf of the European Geosciences Union. 
Table 1. Parameters of the considered tsunamigenic seismic sources from Álvarez-Gómez et al. (2010a,b).

\begin{tabular}{|c|c|c|c|c|c|c|c|c|c|c|c|c|c|}
\hline \multirow[b]{2}{*}{ Source } & \multicolumn{4}{|c|}{ source trace tips } & \multirow{2}{*}{$\begin{array}{l}\mathrm{km} \\
\text { top }\end{array}$} & \multirow{2}{*}{$\begin{array}{r}\mathrm{km} \\
\text { bottom }\end{array}$} & \multirow{2}{*}{$\begin{array}{r}\mathrm{km} \\
\text { length }\end{array}$} & \multirow{2}{*}{$\begin{array}{r}\mathrm{km} \\
\text { width }\end{array}$} & \multirow{2}{*}{$\begin{array}{r}\circ \\
\operatorname{dip}\end{array}$} & \multirow{2}{*}{$\begin{array}{c}\circ \\
\text { strike }\end{array}$} & \multicolumn{2}{|l|}{$\circ$} & \multirow{2}{*}{$\begin{array}{r}\mathrm{m} \\
\text { slip }\end{array}$} \\
\hline & $\mathrm{x} 1$ & y1 & $\mathrm{x} 2$ & $\mathrm{y} 2$ & & & & & & & rake & $M_{\mathrm{W}}$ & \\
\hline \multicolumn{14}{|l|}{ Alboran } \\
\hline ARNFE & -3.283 & 35.900 & -2.938 & 36.079 & 0 & 11 & 37 & 12.7 & 60 & 57 & 45 & 6.71 & 1.02 \\
\hline ARNFW & -3.742 & 35.575 & -3.437 & 35.894 & 0 & 11 & 45 & 11.4 & 75 & 38 & 10 & 6.74 & 1.07 \\
\hline ARSFE & -2.686 & 36.001 & -3.596 & 35.606 & 0 & 11 & 93 & 12.7 & 60 & 242 & 70 & 7.1 & 1.56 \\
\hline ARSFW & -3.720 & 35.536 & -4.280 & 35.289 & 0 & 11 & 58 & 12.7 & 60 & 242 & 70 & 6.91 & 1.32 \\
\hline $\mathrm{TBF}$ & -4.266 & 35.550 & -3.734 & 35.642 & 0 & 11 & 49 & 15.56 & 45 & 78 & 75 & 6.92 & 1.34 \\
\hline CFS & -2.667 & 36.495 & -3.064 & 36.288 & 0 & 11 & 42 & 11.04 & 85 & 237 & 15 & 6.7 & 1.01 \\
\hline $\mathrm{CFC}$ & -2.673 & 36.495 & -2.326 & 36.748 & 0 & 11 & 42 & 11.04 & 85 & 48 & 15 & 6.7 & 1.01 \\
\hline CFN & -2.324 & 36.751 & -1.858 & 37.059 & 0 & 11 & 54 & 11.04 & 85 & 50 & 15 & 6.81 & 1.16 \\
\hline $\mathrm{CFC}+\mathrm{CFN}$ & - & - & - & - & 0 & 11 & 96 & 11.04 & - & - & - & 7.08 & 1.57 \\
\hline $\mathrm{CFS}+\mathrm{CFC}+\mathrm{CFN}$ & - & - & - & - & 0 & 11 & 138 & 11.04 & - & - & - & 7.24 & 1.9 \\
\hline YFE & -2.987 & 36.098 & -2.082 & 35.952 & 0 & 10 & 83 & 10.15 & 80 & 101 & 170 & 6.96 & 1.39 \\
\hline YFW & -1.038 & 35.690 & -2.090 & 35.862 & 0 & 10 & 97 & 10.15 & 80 & 282 & -170 & 7.03 & 1.51 \\
\hline \multicolumn{14}{|l|}{ North Algeria } \\
\hline $\mathrm{S}-0$ & 0.135 & 36.317 & 0.678 & 36.557 & 0.5 & 13 & 55 & 16 & 50 & 61 & 90 & 7.3 & 4 \\
\hline S-1 & 1.262 & 36.700 & 1.881 & 36.738 & 0.5 & 13 & 55 & 16 & 50 & 86 & 90 & 7.3 & 4 \\
\hline$S-2$ & 1.869 & 36.842 & 2.480 & 36.919 & 0.5 & 13 & 55 & 16 & 50 & 81 & 90 & 7.3 & 4 \\
\hline S-3 & 2.583 & 36.961 & 3.204 & 36.962 & 0.5 & 13 & 55 & 16 & 50 & 90 & 90 & 7.3 & 4 \\
\hline S-4 & 3.449 & 36.809 & 3.964 & 37.084 & 0.5 & 13 & 55 & 16 & 50 & 56 & 90 & 7.3 & 4 \\
\hline S-5 & 4.082 & 37.085 & 4.703 & 37.071 & 0.5 & 13 & 55 & 16 & 50 & 92 & 90 & 7.3 & 4 \\
\hline S-6 & 4.576 & 36.905 & 5.119 & 37.146 & 0.5 & 13 & 55 & 16 & 50 & 61 & 90 & 7.3 & 4 \\
\hline S-7 & 5.400 & 36.713 & 5.916 & 36.988 & 0.5 & 13 & 55 & 16 & 50 & 56 & 90 & 7.3 & 4 \\
\hline S-8 & 5.916 & 36.988 & 6.472 & 37.207 & 0.5 & 13 & 55 & 16 & 50 & 64 & 90 & 7.3 & 4 \\
\hline S-9 & 6.637 & 36.981 & 7.180 & 37.221 & 0.5 & 13 & 55 & 16 & 50 & 61 & 90 & 7.3 & 4 \\
\hline
\end{tabular}

While a regional warning system is beneficial for the whole area, the proximity of some tsunamigenic sources to the Spanish coast makes the development of a local warning system essential.

In this paper, we characterise the potential tsunamis generated by sources close to the Iberian Peninsula in the Mediterranean area. The objective is to identify the hazardous sources and the areas where the impact of tsunamis is greater.

\section{Seismic sources}

At the Western end of the Mediterranean, two distinct areas can be defined in terms of geology and tectonics. On the one hand, we have the Alboran Sea environment, characterised by a dominant transcurrent tectonic type and secondly, the Tell Atlas belt, Northern Algeria, characterised by a compressive type of deformation forming thrusts and folds. Both areas were incorporated by Papadopoulos and Fokaefs (2005) as a tsunamigenic zone with intermediate potential based on historical records of tsunamis.

The Northern African coast is geologically formed by the Rif-Tell-Atlas mountain range. An orogenic system built up approximately from the Paleocene-Eocene to the present, in the context of the Alpine orogeny, which configured the present orography of the Mediterranean borders. The ac- tive deformation of the area is caused by the North-NorthWestward motion of the African plate towards the Eurasian plate, taking the latter as fixed. The rate of motion is 4 $6 \mathrm{~mm} / \mathrm{yr}$ (DeMets et al., 1990; McClusky et al., 2003; Serpelloni et al., 2007). This motion is accommodated here by a system of thrusts and folds striking NE-SW to E-W, with a double vergence, towards the South-East and towards the North-West. These structures are interpreted in the context of a transpressive system (Morel and Meghraoui, 1996). This area absorbs around $2-4 \mathrm{~mm} / \mathrm{yr}(40-60 \%)$ of the total convergence between the plates (Morel and Meghraoui, 1996; Meghraoui and Doumaz, 1996; Serpelloni et al., 2007). The mentioned tectonic structures, frequently known as seismogenic inland (Bezzeghoud et al., 1995; Yelles-Chaouche et al., 2003), have their continuation offshore and are the most probable sources of tsunamis in the area (Alasset et al., 2006).

In this tectonic context, we have used tsunamigenic seismic sources proposed in the database of the European project TRANSFER and published by Álvarez-Gómez et al. (2010b). Basically, there are 9 seismic sources whose characteristics are similar to those responsible for the earthquakes in El-Asnam, 1980 and Boummerdes-Zemmouri, 2003. These sources represent low-angle reverse faults verging towards the North and North-West capable of generating $M_{\mathrm{w}}=7.3$ earthquakes. These faults form the Northern 


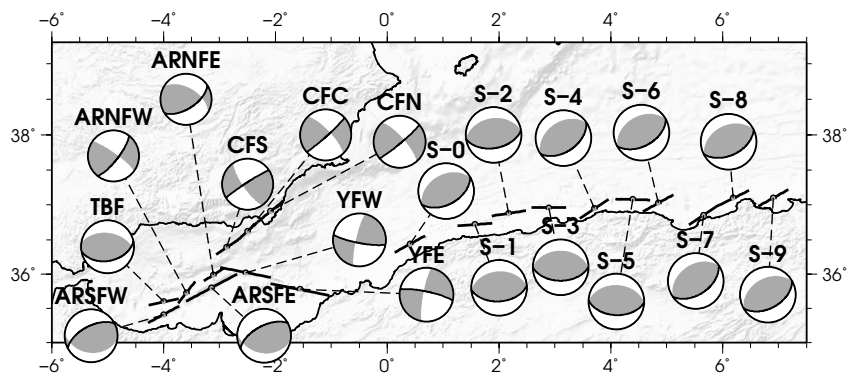

Fig. 1. Seismic sources modelled as probable tsunamigenic worst cases for the Spanish Mediterranean coast (taken from ÁlvarezGómez et al., 2010a,b). The thick lines are the surface trace of the faults and the focal mechanisms represent the rupture characteristics. The black line of each double couple is the fault plane.

boundary of the deformation belt of North Africa's Atlas material thrusting over the Algero-Balearic basin. We model not only the threat of these sources on the coast of the island of Majorca, as did Álvarez-Gómez et al. (2010b), but also the Balearic Islands and the Mediterranean coast of the Iberian Peninsula. To the nine mentioned sources, we have added a new one with the same characteristics, but located on the Western edge of the thrust belt, with convergence towards the NW (S-0 in Fig. 1).

The other area of the study zone is the Alboran Sea, located between the Betic Cordillera (Southern Spain) and the Rif (Northern Morocco). The continental crust of the Alboran Domain has been thinned during the early and middle Miocene. Therefore, its mechanical behaviour contrasts with that surrounding tectonic blocks. The active tectonics of the Alboran Basin is mainly characterised by the relevant strike-slip fault systems; active since at least the late Tortonian times (7-9 Ma) (Bourgois et al., 1992; Comas et al., 1992; Woodside and Maldonado, 1992). Two families of conjugate strike-slip fault systems are active in the Alboran Basin. The main branches of this conjugate system are the left-lateral system that runs from Almeria in South-Eastern Spain towards El Jebha in Northern Morocco, known as the Trans-Alboran Shear Zone (TASZ) (Larouzière et al., 1988; Fernández-Ibáñez et al., 2007); and the right-lateral that runs from Northern Algeria towards Malaga in Southern Spain. The NE-SW trending structures have been described as transpressive, being mainly left-lateral with dip-slip reverse component (Bourgois et al., 1992; Watts et al., 1993; Martínez-Díaz, 2002; Masana et al., 2004; Booth-Rea et al., 2004; Gràcia et al., 2006), while the WNW-ESE structures are mainly right-lateral presenting normal dip-slip component in some areas (Álvarez-Marrón, 1999).

Just as the sources of Northern Algeria, these faults are part of the database of tsunamigenic sources generated in the TRANSFER project and a detailed study of these has been carried out by Álvarez-Gómez et al., 2010a. In this work, the authors compiled works in oceanography and tectonics of the basin, characterising a total of 10 fault segments and 12 potential earthquake ruptures (including the possible rupture of more than one segment per event in the Carboneras fault). These are the sources used in the Alboran Sea area (Fig. 1).

\section{Numerical model}

The model used in the present study is the COMCOT (Cornell Multi-grid Coupled Tsunami) Model. This model is based on the finite difference scheme and has been used to investigate several historical tsunami events in the past: 1960 Chilean tsunami (Liu et al., 1994), 1992 Flores Islands (Indonesia) tsunami (Liu et al., 1995), 2004 Indian Ocean tsunami (Wang and Liu, 2006) and 2003 Algerian tsunami (Wang and Liu, 2005). Additionally, the model has been validated using the benchmark cases proposed in the working frame of the European Tsunami Project TRANSFER. The initial sea bottom deformation used to start the wave propagation has been computed by means of the Okada (1985) equations from the rupture parameters shown in Table 1. We assume an almost instantaneous deformation that is fully transmitted to the sea bottom. Reported values of rupture velocity over a fault in an earthquake range from 2 to $6 \mathrm{~km} / \mathrm{s}$ (Young et al., 1989; Hartzell and Liu, 1996; Sekiguchi and Iwata, 2002; Umutlu et al., 2004). Considering the water incompressible, this deformation is translated instantaneously in sea surface disturbance.

The model solves both nonlinear and linear shallow water equations, adopting a modified leap-frog scheme. Its nesting capabilities make it possible to simulate tsunami generation and its propagation from the source zone to a given coastal area, considering the possible inundation of coastal zones. In the Mediterranean region, earthquake-generated tsunamis are expected to present wave lengths between 20 and $5 \mathrm{~km}$ (Wang and Liu, 2005), while maximum water depths are of the order of $3 \mathrm{~km}$. In these circumstances, wave dynamics can be considered mainly horizontal, the vertical accelerations being negligible and, thus, the pressure field can be assumed to be hydrostatic. The propagation of this kind of waves can be correctly simulated using the shallow water wave equations. In a Cartesian coordinate system these equations can be expressed as:

Mass conservation equation:

$\frac{\partial \zeta}{\partial t}+\frac{\partial P}{\partial x}+\frac{\partial Q}{\partial y}=0$

Momentum conservation equations:

$$
\begin{aligned}
& \frac{\partial P}{\partial t}+\frac{\partial P^{2}}{\partial \mathrm{x}}+\frac{\partial P Q}{\partial \mathrm{y}}+g H \frac{\partial \zeta}{\partial \mathrm{x}}+\tau_{\mathrm{x}} H-f Q=0 \\
& \frac{\partial P}{\partial t}+\frac{\partial P Q}{\partial \mathrm{x}}+\frac{\partial Q^{2}}{\partial \mathrm{y}}+g H \frac{\partial \zeta}{\partial \mathrm{y}}+\tau_{\mathrm{y}} H-f P=0
\end{aligned}
$$


Where $\zeta$ is the free surface elevation above the mean sea level, $\mathrm{x}$ and $\mathrm{y}$ represent the longitude and latitude of the earth, $\tau_{\mathrm{x}}$ and $\tau_{\mathrm{y}}$ are the bottom shear stress in the $\mathrm{x}$-axis (pointing to the East) and y-axis pointing to the North, $P$ and $Q$ stand for the volume fluxes $(P=H u$ and $Q=H v$ with $u$ and $v$ being the depth-averaged velocities in the longitude and latitude direction), $H$ is the total water depth $(H=h+\zeta)$ with $h$ being the water depth, $f$ represents the Coriolis parameter and $g$ is the acceleration due to gravity.

The simulation domain covers the Alboran and AlgeroBalearic basins, in the Western Mediterranean region (Fig. 2. The cell size used is approximately $900 \times 900 \mathrm{~m}\left(30^{\prime \prime} \times 30^{\prime \prime}\right)$, the bathymetry data of GEBCO_08 (GEBCO, 2008) has been utilized. We have used several nested grids, depending on the detailed area, with a resolution of $450 \times 450 \mathrm{~m}\left(15^{\prime \prime} \times 15^{\prime \prime}\right)$. These nested grids have been applied to the Alboran Sea and for each one of the three main Balearic Islands. For all the numerical simulations a radiation boundary condition has been considered in the boundaries falling into the water region, while in all those boundaries separating wet and dry domains, a vertical wall condition has been adopted.

We have computed tsunami travel times following the technique described by Shokin et al. (1987) and implemented by Luis (2007) (these travel times are shown as contours in the Figs. 3, 4, 5, 6, 7, 8). If we assume that the tsunami wave length is much greater than the water depth, the tsunami travel time can be computed taking into account only the water depth: $c^{2}=g h$, where $c$ stands for wave propagation speed, $g$ is the acceleration of gravity and $h$ is the water depth.

\section{Results}

We present the results as maps of Maximum Wave Elevation (MWE) and Tsunami Travel Times (TTT) as contours on these maps. These maps are presented by area of interest, where we have generated a map for each tsunamigenic source.

As shown in Fig. 3, the sources of the Alboran Sea have little impact on the sea level in the Balearic Islands. In the case of the sources in Northern Algeria, the Westernmost sources would be a threat to the South-Eastern coast of the Iberian Peninsula. For the former, the results are presented only in the Alboran Sea, while for the latter the results are presented in the regional mesh to estimate the potential threat on the Iberian Peninsula. The sources of Northern Algeria have been propagated in greater detail on the Balearic Islands.

\subsection{Regional}

As mentioned above, the sources of the Alboran Sea are not capable of generating MWE large enough to be a risk in the Balearic Islands or to the Eastern coast of the Iberian Peninsula. Figure 3 shows the MWE map for the potentially more

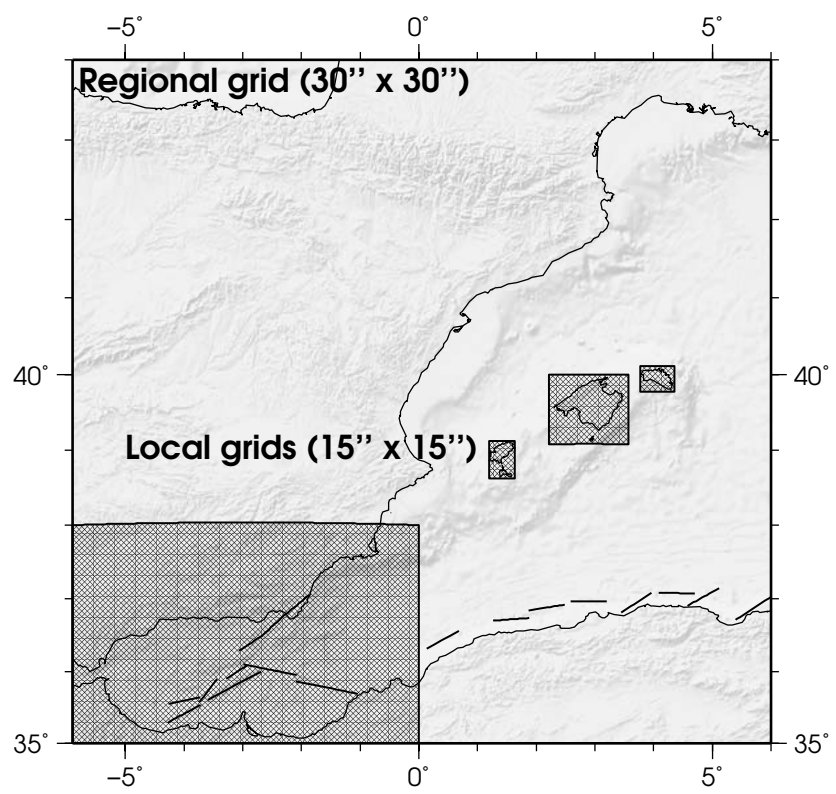

Fig. 2. Used grids. The regional grid has a cell size of $30^{\prime \prime}$ and the local nested grids (shaded rectangles) have cell sizes of $15^{\prime \prime}$.

dangerous source of the Alboran basin, the Alboran Ridge South Eastern Fault segment (ARSFE). This source generates elevations around the $0.5 \mathrm{~m}$ or greater in the Southern Spanish coast between Malaga and Granada while to AlgeroBalearic basin elevations are minimal.

North Western sources in Algeria mainly affect the islands of Ibiza and Formentera, unless the new source introduced in this work (S-0 in Fig. 3) which affects the South-Eastern Spanish coast and the provinces of Murcia and Alicante with elevations greater than $1 \mathrm{~m}$ off the coast of Torrevieja ( $\mathrm{T}$ in Fig. 3). The same S-0 source can generate maximum wave elevations of just over $0.5 \mathrm{~m}$ on the coast of Formentera. S1 produces maximum elevations in Ibiza and Formentera, greater than $1 \mathrm{~m}$, but also off the coast of the Iberian Peninsula this value is exceeded in front of the area of Benidorm. The degree of influence of the S-2 and S-3 sources with respect to the Iberian Peninsula is much lower, only causing local elevations close to $0.5 \mathrm{~m}$ between Cartagena and Benidorm (Ca and $\mathrm{Bn}$ in Fig. 3). The sources located further East, on the North Algerian coast, hardly affect the Iberian coast.

The wave generated at the nearest source of the North of Algeria takes about $20 \mathrm{~min}$ to reach the nearest part of the Iberian coast, the area of Cartagena (Ca in Fig. 3). As the source is situated farther East, the tsunami travel time to the Iberian coast increases. The tsunami travelling from source S-1 takes about $25 \mathrm{~min}$, from source S-2 about $30 \mathrm{~min}$ and from the $\mathrm{S}-3$ about $35 \mathrm{~min}$. The tsunami generated by these sources takes about $30 \mathrm{~min}$ to reach Formentera, which is the closest of the Balearic islands off the coast of Algeria. The 

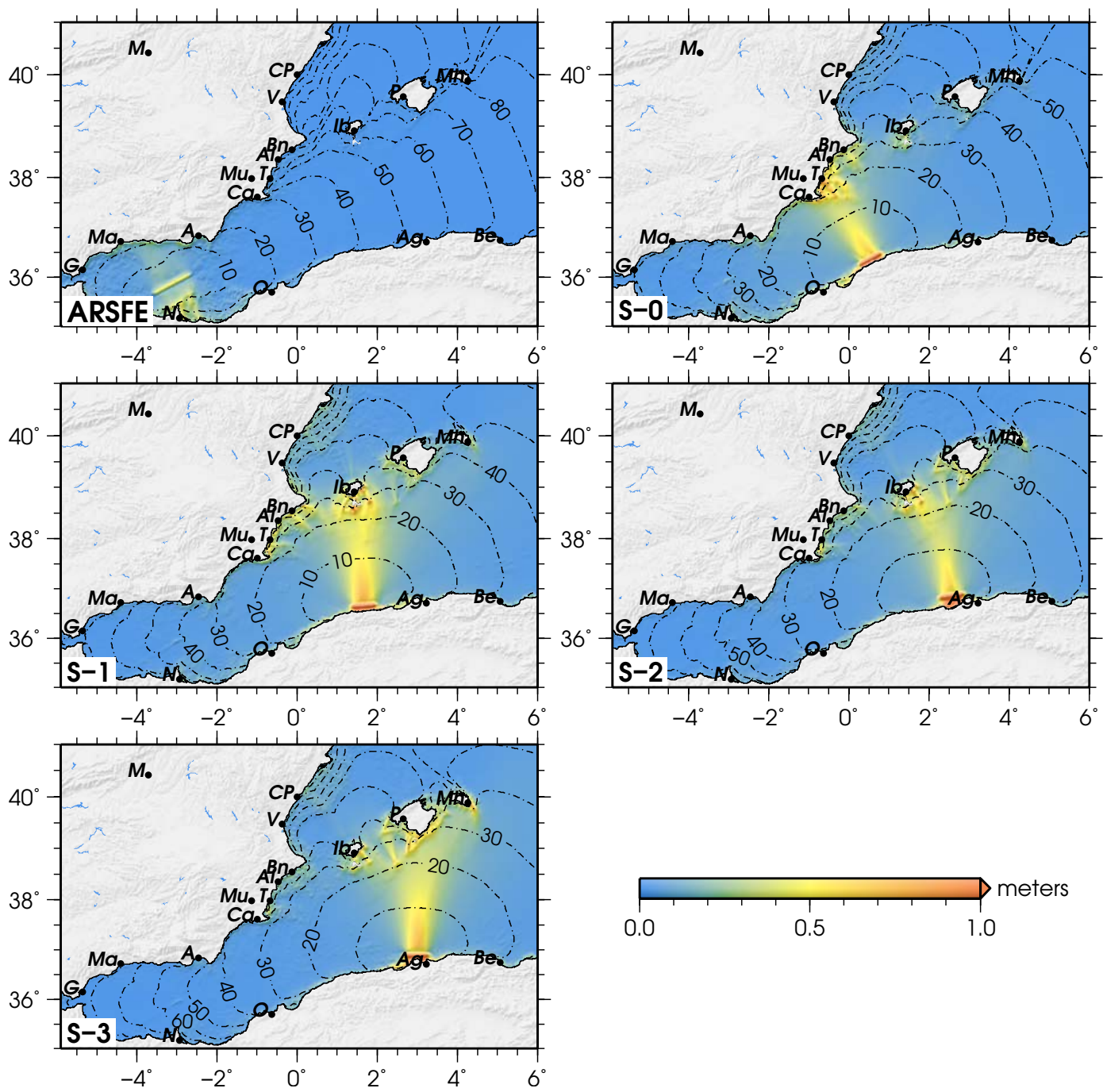

Fig. 3. Regional maximum wave elevation maps for the worst tsunamigenic source of the Alboran Sea according to(Álvarez-Gómez et al., 2010a), the Alboran Ridge South Fault Eastern segment (ARSFE); and for the Northern Algerian sources worst cases for the South-Eastern Iberian Peninsula. The colour shading varies with the maximum wave elevation as shown in the colour scale. The contours are the wave fronts in different time steps from the tsunami generation time; in minutes. Black dots show the location of relevant populations: G, Gibraltar; Ma, Malaga; N, Nador; A, Almeria; O, Oran; Ca, Cartagena; Mu, Murcia; Ag, Alger; Be, Bejaia; Mh, Mahon; P, Palma; Ib, Ibiza; Al, Alicante; Bn, Benidorm; T, Torrevieja; V, Valencia; CP, Castellon de la Plana; M, Madrid.

time is about 40-50 min until it reaches Minorca, the most remote island. These times and elevations are seen in more detail later. A hypothetical tsunami caused in the Alboran Sea would take just over an hour to reach the Balearic Islands, although, as mentioned above, the elevation of the wave generated is minimal and probably would only be recorded by tide gauges.

\subsection{Alboran Sea}

If we compare Figs. 4 and 5 it becomes clear that the sources present in the former have more capacity to generate dangerous waves at the Spanish coast than in the latter. The Sources in Fig. 5 are all mainly of strike-slip type, which produce quite low vertical deformation on the sea bottom for the magnitude of the event. Only the structures with a more important reverse fault character, those related to the Alboran Ridge (ARNFE, ARSFE, ASFW and TBF), produce wave elevations in excess of $0.5 \mathrm{~m}$.

The Spanish coastal area most affected by sources of the Alboran Sea is known as "Costa del Sol", between Marbella, in the province of Malaga and the area of Punta Entinas, near the city of Almeria. In this area, especially on the coast of Granada, maximum wave elevations can locally exceed $1 \mathrm{~m}$. These sources, located at the South-central area of the Alboran Basin, have estimated tsunami travel times to the "Costa del Sol" ranging from $15 \mathrm{~min}$, off the coast of Almeria and 

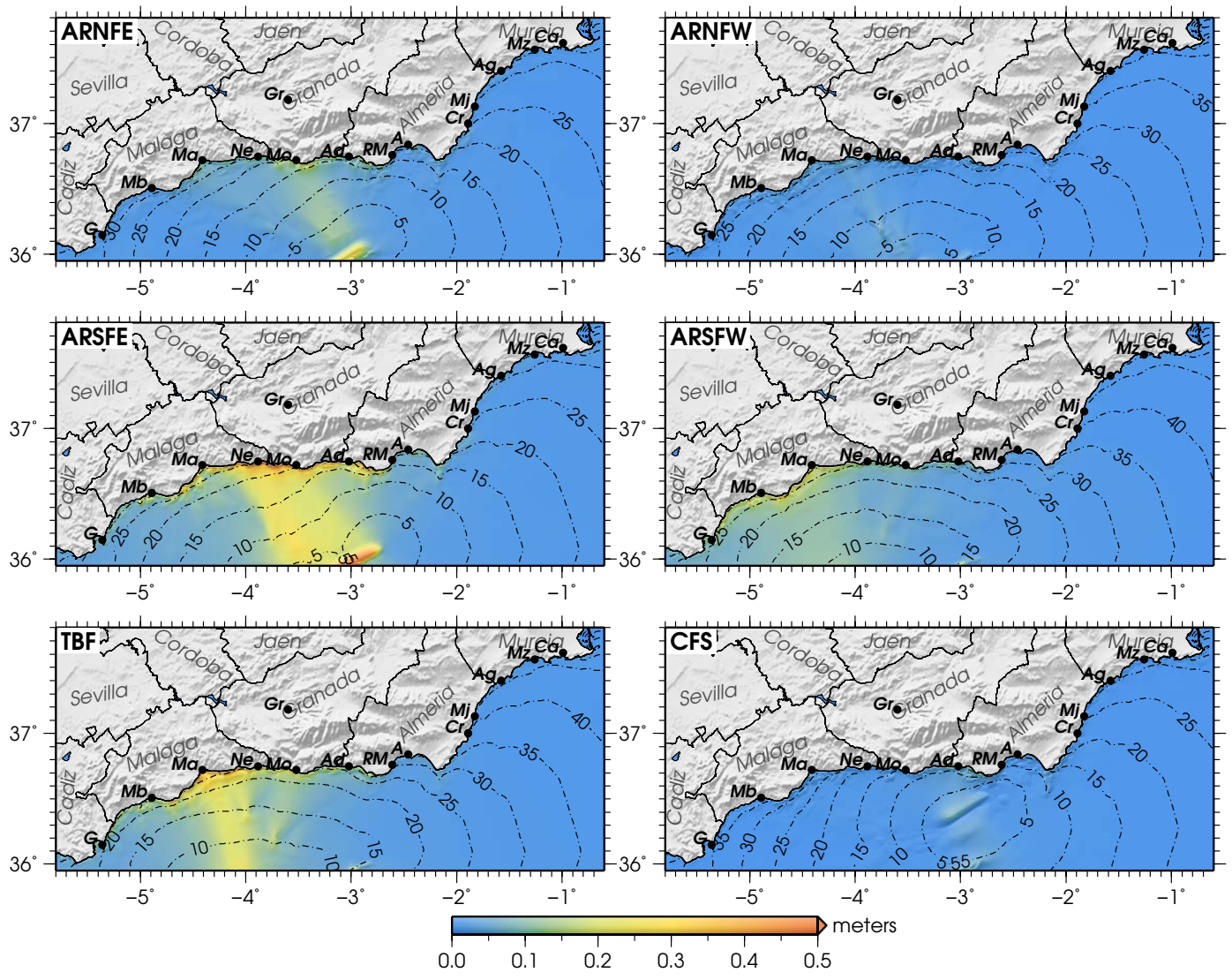

Fig. 4. Maximum wave elevation maps and estimated tsunami travel times in the Alboran Sea. The shading represents the wave elevation value as shown in the colour scale at the bottom. The contours show the tsunami travel time in 5 min steps from the source. ARNFE: Alboran Ridge Northern Fault East segment; ARNFW: Alboran Ridge Northern Fault West segment; ARSFE: Alboran Ridge Southern Fault East segment; ARSFW: Alboran Ridge Southern Fault West segment; TBF: Tofiño Bank Fault; CFS: Carboneras Fault Southern segment. Black dots show the location of relevant populations: G, Gibraltar; Mb, Marbella; Ma, Malaga; Gr, Granada; A, Almeria; Ca, Cartagena; Mo, Motril; Ad, Adra; RM, Roquetas de Mar; Cr, Carboneras; Mj, Mojacar; Ag, Aguilas; Mz, Mazarron; Ne, Nerja.

Granada for the ARNFE source, up to $35 \mathrm{~min}$ for the same source on the coast of Malaga. That is, in less than $30 \mathrm{~min}$ most of the "Costa del Sol" would be hit by waves that might be of some importance.

Strike-slip faults of the Alboran basin, the Carboneras and Yusuf faults, do not have a high potential to generate destructive tsunamis, although they could generate tsunamis affecting the coastal infrastructure with a short travel time, less than 5 min (Fig. 5).

\subsection{Balearic Islands}

As mentioned previously, only the seismic sources in Northern Algeria are capable of generating tsunamis with relevance to the Balearic Islands. The seismic sources considered in the Alboran Sea hardly pose a threat to these islands. Due to the directivity of propagation, perpendicular to the direction of the fault, each of the sources affects mainly the island that is placed in front. Thus, Western sources mainly affect the islands of Ibiza and Formentera, while the Eastern particularly affect the island of Minorca. In this case, these sources have NE-SW direction, and will also affect the island of Majorca (see Figs. 1 and 2).

\subsubsection{Ibiza and Formentera}

The Western sources North of Algeria with E-W direction, the S-1 and S-2, affect mainly the coast of Ibiza and Formentera. Maximum wave elevation values of $2 \mathrm{~m}$ are exceeded quite generally South of both islands, especially South of the island of Formentera, where values exceeding $4 \mathrm{~m}$ are present in the vicinity of Cap de Barbária (CB in Fig. 6). Another area particularly affected is located on the island of Ibiza, the area of Es Canar, where the wave elevation also reaches $4 \mathrm{~m}$ with the source S-2 (EC in Fig. 6). Besides these two major sources in Ibiza and Formentera, the sources S-3, S-4 and S- 6 can also generate wave elevations close to $2 \mathrm{~m}$. The Cap de Barbária area concentrates 

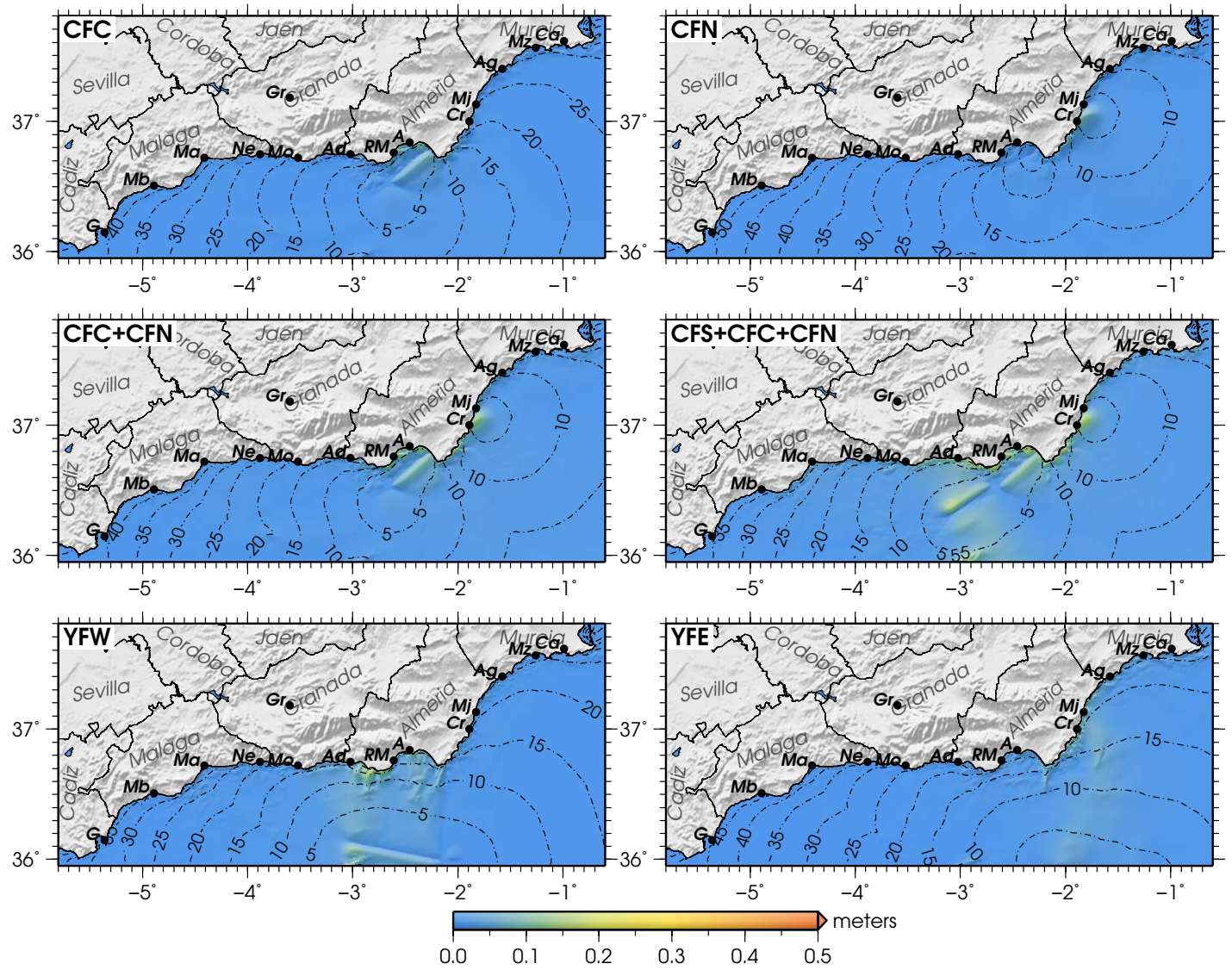

Fig. 5. Maximum wave elevation maps and estimated tsunami travel times in the Alboran Sea. The shading represents the wave elevation value as shown in the colour scale at the bottom. The contours show the tsunami travel time in 5 min steps from the source. CFC: Carboneras Fault Central segment; CFN: Carboneras Fault Northern segment; CFC + CFN: combination of both segments; CFS + CFC + CFN: combination of the three segments; YFW: Yusuf Fault Western segment; YFE: Yusuf Fault Eastern segment. Black dots show the location of relevant populations: G, Gibraltar; Mb, Marbella; Ma, Malaga; Gr, Granada; A, Almeria; Ca, Cartagena; Mo, Motril; Ad, Adra; RM, Roquetas de Mar; Cr, Carboneras; Mj, Mojacar; Ag, Aguilas; Mz, Mazarron; Ne, Nerja.

important elevations as well as the NE end of the island of Ibiza. A potential tsunami generated in one of the sources S-1, S-2 or S-3 reaches the South-Eastern tip of Formentera in about $30 \mathrm{~min}$, and the island of Ibiza in just over $40 \mathrm{~min}$. Tsunami sources S-4 and S-5 can take up to 5 min longer to arrive, around 35 and 45 min, respectively, to Formentera and Ibiza.

\subsubsection{Majorca}

The island of Majorca, located in a central position, is affected at a greater or lesser extent by all sources modelled in Northern Algeria, being the sources S-3, S-5, S-6 and S-8 which generate a greater impact on the coast. Of these four sources the $\mathrm{S}-3$ is the highest risk, generating wave elevations above $1 \mathrm{~m}$ practically on all the South sides of the island, locally greater than $2 \mathrm{~m}$. The other three sources, S-5, S-6 and $\mathrm{S}-8$, have a greater impact on the South-East part of the island and also in the North-East, where maximum wave elevations greater than $1 \mathrm{~m}$ are generated in the Bay of Alcudia $(\mathrm{CP}$ and PA in Fig. 7).

Sources S-1, S-2, S-4, S-7 and S-9 are the ones that have less impact on the island. These sources only generate maximum wave elevations close to $1 \mathrm{~m}$, although above $0.5 \mathrm{~m}$. Sources S-7 and S-9 primarily affect the Eastern part of the island, while the S-1, S-2 and S-4 especially on the Western part.

The tsunami travel time for the nearest sources is around 30 min to the island of Cabrera and 35 to the South coast of Majorca. The waves take about 20 min longer to reach the bay of Palma (P in Fig. 7) and Alcudia (PA in 7), and $30 \mathrm{~min}$ to reach the North side of the island. 

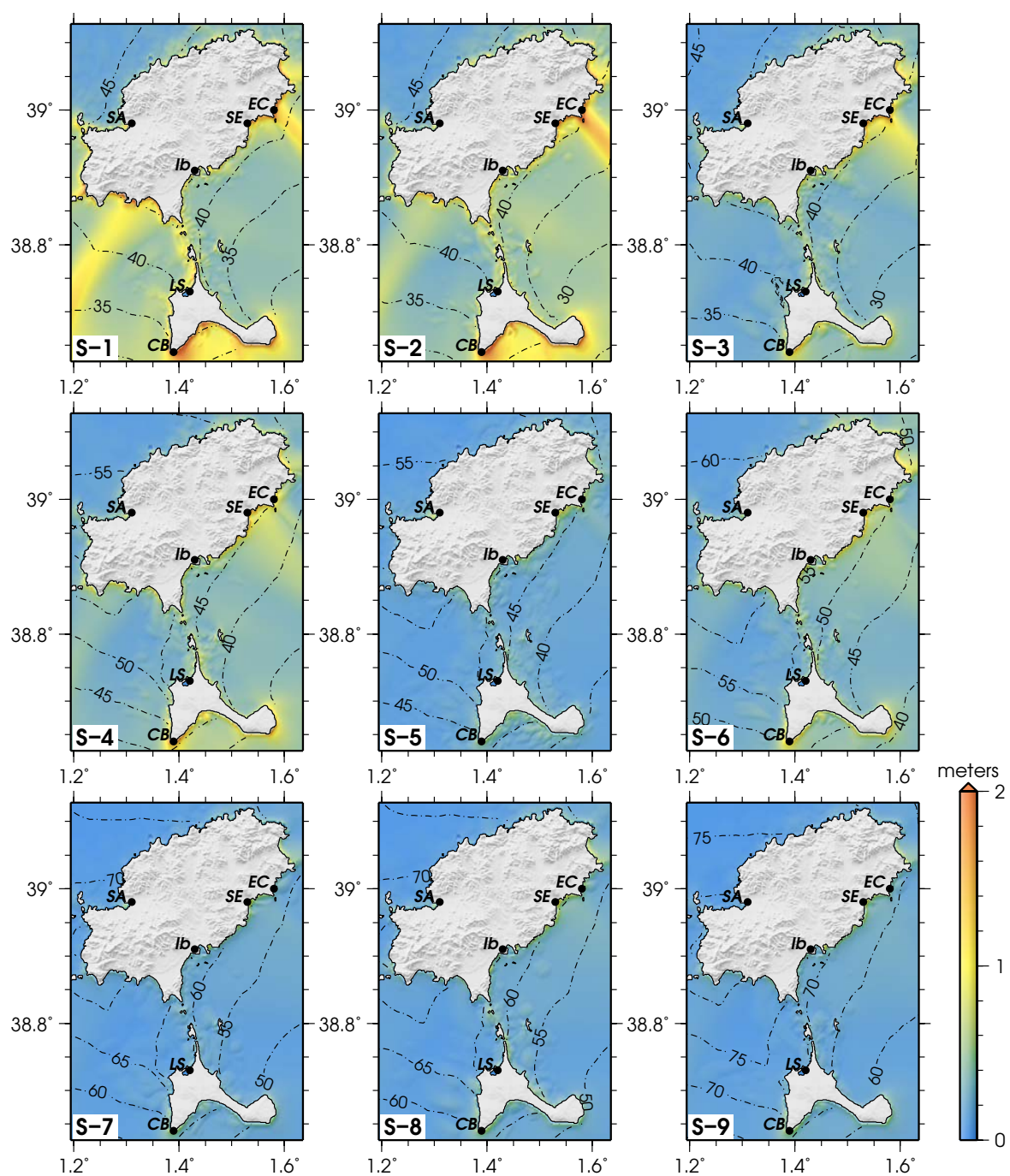

Fig. 6. Maximum wave elevation maps and estimated tsunami travel times for the islands of Ibiza and Formentera. The shading represents the wave elevation value as shown in the colour scale at the right. The contours show the tsunami travel time in 5 min steps from the source. Black dots show the location of relevant populations: Ib, Ibiza; SE, Santa Eulària des Riu; EC, Es Canar; SA, Sant Antoni de Portmany; LS, La Savina; CB, Cap de Barbária.

\subsubsection{Minorca}

Of all the sources, S-5 and S-8 are responsible for creating the most dangerous tsunamis for the island of Minorca. In both cases, maximum wave elevations above $2 \mathrm{~m}$ are generated in the South-East corner of the island, and over $1 \mathrm{~m}$ generally throughout the South and East façades of the island (Fig. 8). In general the South-East rim is the area most affected by all the tsunamis. In addition to the sources S-5 and $\mathrm{S}-8$, there are others that generate tsunamis with maximum wave elevations above $1 \mathrm{~m}, \mathrm{~S}-3, \mathrm{~S}-6$ and S-9. Significant maximum wave elevations are often also generated in the bay of Mahón, the main city of the island, especially with sources S-3, S-5 and S-8. Regarding the tsunami travel time, in all cases this is between 40 and 45 min, taking about 2025 min more to reach the North side of the island and at low intensity.

\section{Discussion}

To better understand the implications of the elevations calculated with our numerical models, we have to take into account that the height of flooding, or run-up, will be much higher than the elevation.

Run-up formulations can obtain the maximum flood height at different cross-sections along the coast, depending on whether the tsunami wave has broken or not, the tsunami wave height, the water depth, the average coast slope and 

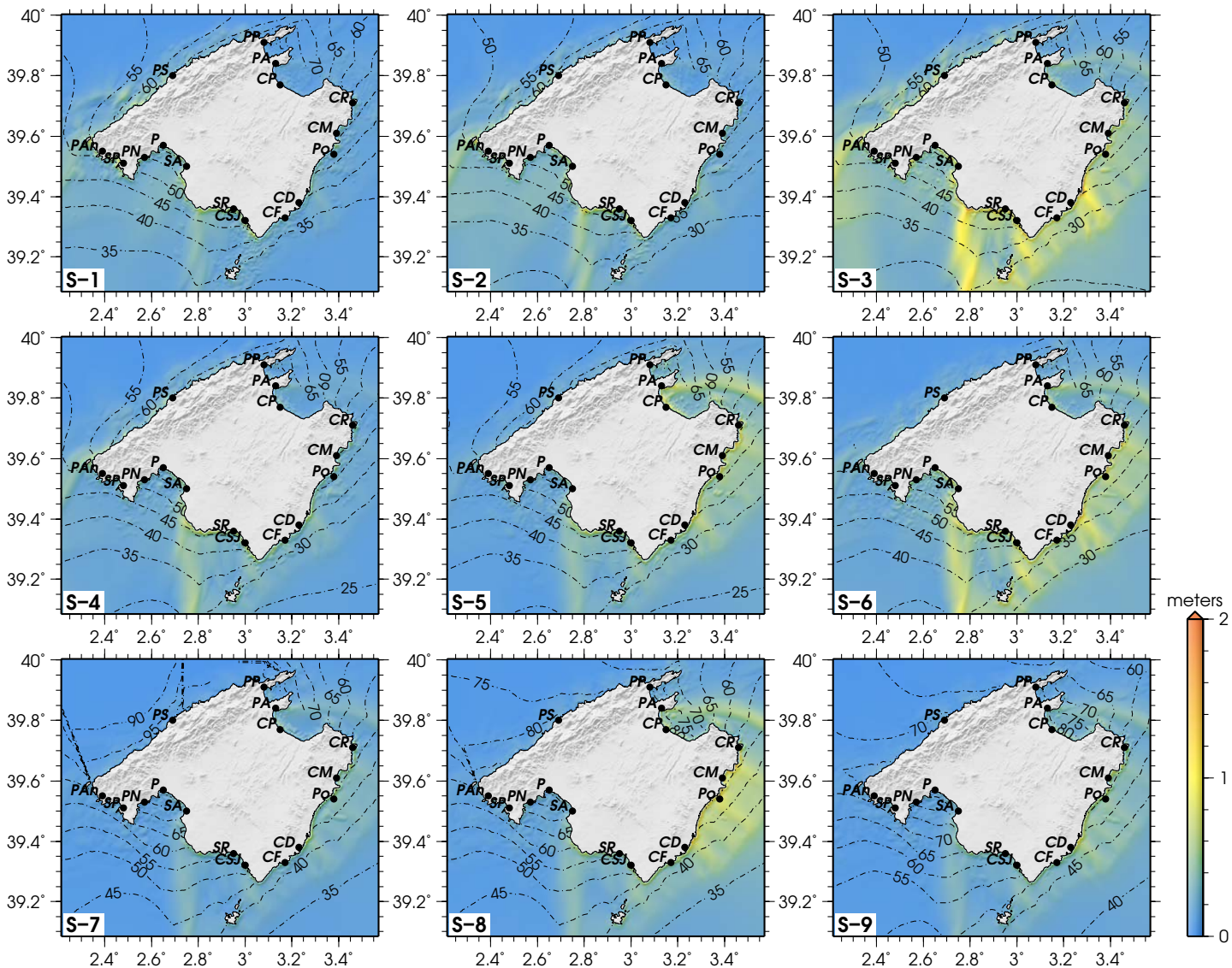

Fig. 7. Maximum wave elevation maps and estimated tsunami travel times for Majorca Island. The shading represents the wave elevation value as shown in the colour scale at the right. The contours show the tsunami travel time in 5 min steps from the source. Black dots show the location of relevant populations: P, Palma; SR, Sa Rapita; CSJ, Colònia Sant Jordi; CF, Cala Figuera; CD, Cala D’Or; Po, Portocristo; CM, Cala Millor; CR, Cala Rajada; CP, Can Picafort; PA, Port d'Alcudia; PP, Port de Pollença; PS, Port de Soller; PAn, Port d'Andratx; SP, Santa Ponça; PN, Portals Nous; SA, S’Arenal.

other local parameters. With these formulations maximum flood levels, associated with these tsunami waves, are obtained and allow a local flood mapping approximation. One of the formulations used in this type of work is the Synolakis (1987) formulation of run-up $R$ :

Non-breaking wave:

$R / d=2.831 \cdot(\cot \beta)^{1 / 2} \cdot(H / d)^{5 / 4}$

Breaking wave:

$R / d=0.918 \cdot(H / d)^{0.606}$

where $R$ is the run-up height, $d$ the depth where the elevation is obtained, $\beta$ the slope of the bottom and $H$ the value of the elevation.

The long wave breaking criteria of Gjevik and Pedersen (1981) is used to select the run-up formulation:

$H / d>0.8183 \cdot(\cot \beta)^{-10 / 9}$

The mean cross-shore slope $\beta$ between the shoreline and water depth $(d=10 \mathrm{~m})$, has been characterised along the coast in the peninsula and the islands. With mean slopes between 1:10 (for areas with a mean sediment size $\mathrm{D} 50=10 \mathrm{~mm}$ ) and 1:40 (for coastal areas with sediment size $\mathrm{D} 50=0.5 \mathrm{~mm}$ ). In both cases, the breaking criteria of Gjevik and Pedersen (1981) predicts breaking waves for elevations higher to some decimetres.

According to the application of this formulation in other places such as the coast of Central America (Brizuela et al., 2009), it works quite well in coastal areas where the tsunami generates flooding, presenting limitations in areas of water bodies like estuaries, river mouths, areas of wetlands, etc. The flooding achieved with this formulation of run-up (Synolakis, 1987) in the coastal zone provides more conservative flood areas compared to the results of the numerical models. This is because the numerical model includes terms for dissipation by turbulence (breaking waves) and bottom friction, obtaining shorter flooding distances.

If we use the breaking wave formulation with the threat level limits proposed by Tiberti et al. (2008), based on the 

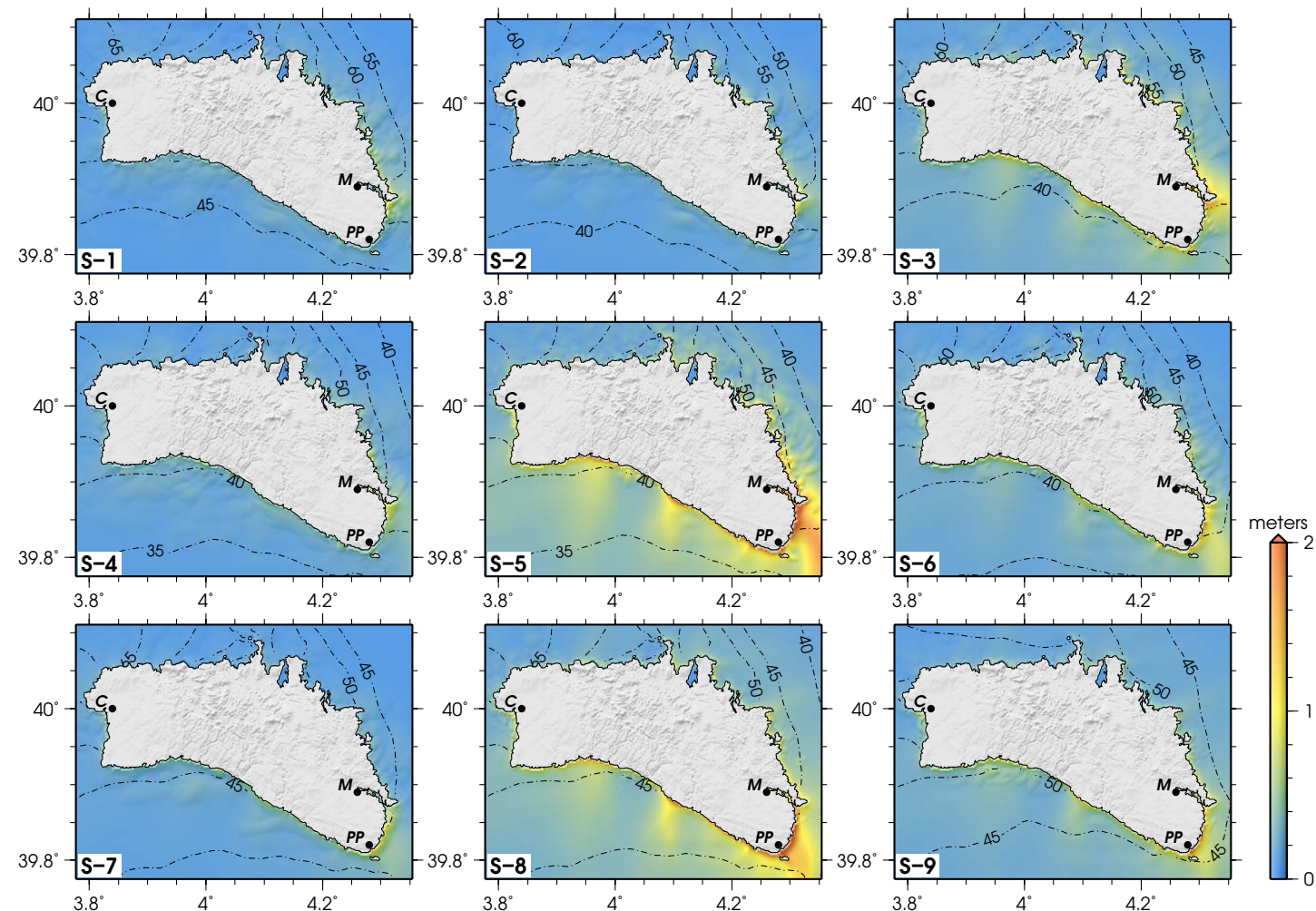

Fig. 8. Maximum wave elevation maps and estimated tsunami travel times for the Minorca Island. The shading represents the wave elevation value as shown in the colour scale at the right. The contours show the tsunami travel time in 5 min steps from the source. Black dots show the location of relevant populations: PP, Punta Prima; M, Mahón; C, Ciutadella.

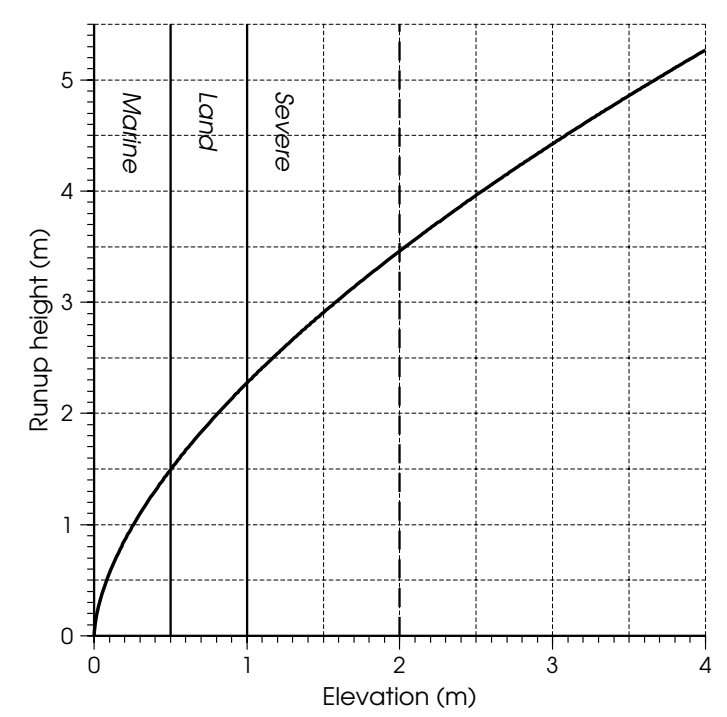

Fig. 9. Graph showing the wave elevation - run-up height relation of Synolakis (1987) for a breaking wave. The thick vertical grid lines show the threat levels of Tiberti et al. (2008). maximum wave elevation for the $10 \mathrm{~m}$ isobath, we obtain the following run-up heights (RH) for a slope of 1:20 (this slope influences the breaking criteria and the formulation of non-breaking wave) (Fig. 9):

- No threat

MWE $<0.05 \mathrm{~m}$

$\mathrm{RH}<0.17 \mathrm{~m}$ (non-breaking wave)

- Marine threat

$0.05 \mathrm{~m} \leq \mathrm{MWE}<0.5 \mathrm{~m}$

$0.17 \mathrm{~m} \leq \mathrm{RH}<1.5 \mathrm{~m}$ (breaking wave)

- Land threat

$0.5 \mathrm{~m} \leq \mathrm{MWE}<1 \mathrm{~m}$

$1.5 \mathrm{~m} \leq \mathrm{RH}<2.3 \mathrm{~m}$ (breaking wave)

- Severe Land threat

$1 \mathrm{~m} \leq \mathrm{MWE}$

$2.3 \mathrm{~m} \leq \mathrm{RH}$ (breaking wave)

In Table 2 a summary of the threat level for each of the sources over the South-Eastern Spanish provinces of the Iberian peninsula and the Balearic Islands is presented. The threat level has been assigned according to the classification used by Tiberti et al. (2008) to which we added a fourth level 
Table 2. Threat level of the considered sources on the Spanish coasts of the Iberian Peninsula and Balearic Islands depending on the Maximum Wave Elevation (MWE) at the isobath of $10 \mathrm{~m}$. The numbers refer to the level of threat: $0-$ No threat (MWE $<0.05 \mathrm{~m}$ ); $1-$ Marine threat $(0.05 \mathrm{~m}<\mathrm{MWE}<0.5 \mathrm{~m}) ; 2$-Land threat $(0.5 \mathrm{~m}<\mathrm{MWE}<1 \mathrm{~m}) ; 3$-Severe Land threat $(1 \mathrm{~m}<\mathrm{MWE}<2 \mathrm{~m}) ; 4-\mathrm{Severe}$ Land threat with maximum wave elevations over $2 \mathrm{~m}(\mathrm{MWE}>2 \mathrm{~m})$. The "total" column shows the sum of the threat levels on the different provinces and islands. The $\%$ is the normalized threat. See text for further explanations.

\begin{tabular}{|c|c|c|c|c|c|c|c|c|c|c|c|c|}
\hline \multirow[b]{2}{*}{ Source } & \multirow[b]{2}{*}{ Cadiz* } & \multirow[b]{2}{*}{ Malaga } & \multicolumn{2}{|c|}{ Iberian Peninsula } & \multirow[b]{2}{*}{ Murcia } & \multirow[b]{2}{*}{ Alicante } & \multicolumn{3}{|c|}{ Balearic Islands } & \multirow[b]{2}{*}{ Total } & \multirow[b]{2}{*}{$\%$} & \\
\hline & & & Granada & Almeria & & & Ibiza & Majorca & Minorca & & & \\
\hline \multicolumn{13}{|l|}{ Alboran } \\
\hline ARNFE & 0 & 1 & 1 & 1 & 0 & 0 & 0 & 0 & 0 & 3 & 2.1 & \multirow{12}{*}{$23 \%$} \\
\hline ARNFW & 0 & 1 & 0 & 0 & 0 & 0 & 0 & 0 & 0 & 1 & 0.7 & \\
\hline ARSFE & 1 & 2 & 2 & 1 & 0 & 0 & 0 & 0 & 0 & 6 & 4.3 & \\
\hline ARSFW & 1 & 1 & 1 & 1 & 0 & 0 & 0 & 0 & 0 & 4 & 2.9 & \\
\hline TBF & 1 & 2 & 1 & 1 & 0 & 0 & 0 & 0 & 0 & 5 & 3.5 & \\
\hline CFS & 0 & 0 & 1 & 1 & 0 & 0 & 0 & 0 & 0 & 2 & 1.4 & \\
\hline $\mathrm{CFC}$ & 0 & 0 & 0 & 1 & 0 & 0 & 0 & 0 & 0 & 1 & 0.7 & \\
\hline CFN & 0 & 0 & 0 & 1 & 0 & 0 & 0 & 0 & 0 & 1 & 0.7 & \\
\hline $\mathrm{CFC}+\mathrm{CFN}$ & 0 & 0 & 0 & 1 & 0 & 0 & 0 & 0 & 0 & 1 & 0.7 & \\
\hline $\mathrm{CFS}+\mathrm{CFC}+\mathrm{CFN}$ & 0 & 1 & 1 & 1 & 1 & 0 & 0 & 0 & 0 & 4 & 2.9 & \\
\hline YFW & 0 & 0 & 1 & 1 & 0 & 0 & 0 & 0 & 0 & 2 & 1.4 & \\
\hline YFE & 0 & 0 & 0 & 1 & 1 & 0 & 0 & 0 & 0 & 2 & 1.4 & \\
\hline \multicolumn{13}{|l|}{ Algeria } \\
\hline S-0 & 1 & 1 & 1 & 2 & 3 & 2 & 2 & 1 & 1 & 14 & 10 & \multirow{10}{*}{$77 \%$} \\
\hline S-1 & 0 & 1 & 1 & 1 & 2 & 2 & 4 & 2 & 2 & 15 & 10.7 & \\
\hline S-2 & 0 & 1 & 1 & 1 & 2 & 2 & 4 & 2 & 2 & 15 & 10.7 & \\
\hline S-3 & 0 & 0 & 0 & 1 & 1 & 1 & 3 & 3 & 3 & 12 & 8.6 & \\
\hline S-4 & 0 & 0 & 0 & 0 & 1 & 1 & 3 & 2 & 2 & 9 & 6.4 & \\
\hline S-5 & 0 & 0 & 0 & 0 & 0 & 0 & 2 & 3 & 4 & 9 & 6.4 & \\
\hline S-6 & 0 & 0 & 0 & 0 & 1 & 1 & 3 & 3 & 3 & 11 & 7.9 & \\
\hline S-7 & 0 & 0 & 0 & 0 & 0 & 0 & 2 & 2 & 2 & 6 & 4.3 & \\
\hline S-8 & 0 & 0 & 0 & 0 & 0 & 0 & 2 & 3 & 4 & 9 & 6.4 & \\
\hline S-9 & 0 & 0 & 0 & 0 & 0 & 0 & 2 & 3 & 3 & 8 & 5.7 & \\
\hline Total & 4 & 11 & 11 & 16 & 12 & 9 & 27 & 24 & 26 & 140 & - & \\
\hline \multirow[t]{2}{*}{$\%$} & 2.9 & 7.9 & 7.9 & 11.4 & 8.6 & 6.4 & 19.3 & 17.1 & 18.6 & - & 100 & \\
\hline & \multicolumn{6}{|c|}{$45 \%$} & \multicolumn{3}{|c|}{$55 \%$} & & & \\
\hline
\end{tabular}

*In the Cadiz province only the Mediterranean coast and sources are considered.

for maximum wave elevations greater than $2 \mathrm{~m}$, thus, giving a run-up height of $3.5 \mathrm{~m}$ (Fig. 9). To quantify the proportion of the threat from each source and on each province or island, we have assigned points to the threat levels; from 0 for "no-threat" level to 3 for "Land Severe Threat". If the maximum wave elevation overcomes the $2 \mathrm{~m}$ ( $3.5 \mathrm{~m}$ of run-up) the value that is given is 4 points.

While it is true that the run-up height and the real damage of the wave depends largely on the detailed configuration of the bathymetry and the coastal topography, this approach allows us to establish threat levels in regions (usually large) where it is impossible to conduct flood models with the required detail (Allen and Greenslade, 2008). In Fig. 9 estimated values of run-up obtained with the formulation of Synolakis (1987) are shown. Table 2 also includes normalized values for the threat level. The relative contribution of each source to the total threat and the threat proportion of each province or island can then be easily obtained.

As can be seen in Table 2, sources in Northern Algeria are more dangerous than those in the Alboran Sea, $77 \%$ versus $23 \%$. The Alboran Sea sources only pose a risk to the nearest coast and especially by those sources related to the Alboran Ridge. As for the sources of Northern Algeria, the Western ones pose a greater risk because of their ability to also affect the South-Eastern coast of the Iberian Peninsula (Fig. 3). If we only consider the islands then the sources that pose the greatest threat are the S-3, S-5, S-6 and S-8, giving each one a total of 9 points of threat on the islands. The source with less danger from the North of Algeria would be the S-7, proposed as possibly responsible for the earthquake and tsunami of Djijelli in 1856 (Álvarez-Gómez et al., 2010b; Roger and Hébert, 2008).

The Southern coast of the Iberian Peninsula, despite being exposed mainly to less dangerous tsunamigenic sources, has $45 \%$ of the total threat (Table 2). This is due to the large extent of exposed coast in contrast to the Balearic Islands. The province of Almeria is the more exposed of the peninsula, with more than $10 \%$ of total threat, followed by Murcia, Malaga and Granada. In the case of the Balearic Islands, the three islands have a very similar degree of threat, around the $20 \%$ of the total each. 


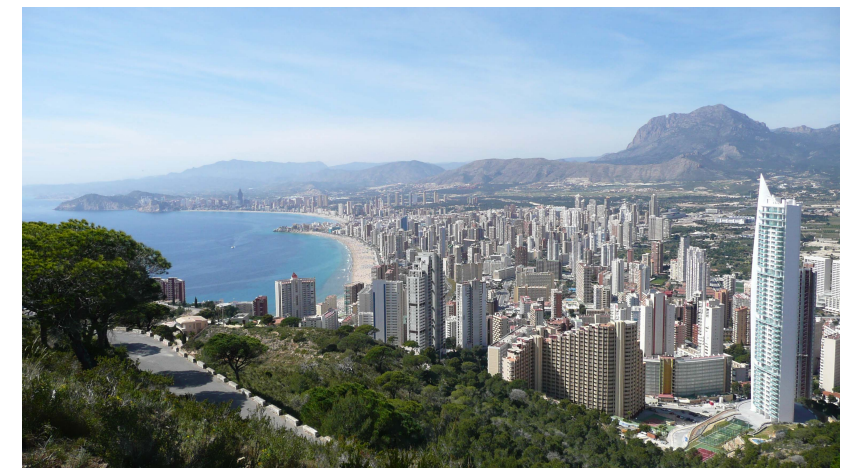

Fig. 10. Photograph of Benidorm, in Alicante; an important tourism centre of the Mediterranean Spanish coast. (Photograph of public domain from Wikimedia Commons).

The South coast of the Iberian Peninsula is threatened mainly by the faults of the Alboran ridge, being the provinces of Malaga and Granada the most affected. The strike-slip faults of the Alboran basin, the Carboneras and Yusuf faults, although lacking in high potential to generate destructive tsunamis, are able to generate earthquakes with high magnitudes, around $M_{\mathrm{w}}=6.7-7$ (Álvarez-Gómez et al., 2010a). In the case of the Carboneras fault, due to its proximity to the Spanish coast, its earthquakes can promote major undersea landslides capable of generating locally destructive tsunamis in the area of Almeria. This province is the most threatened of the South-Eastern peninsula because it is affected by virtually all sources of Alboran and by the Westernmost of North Algeria (Fig. 3), although the threat level is mainly the "Marine" type (Table 2).

The South-East of the Iberian Peninsula is threatened mainly by the North Western faults of Algeria. These sources threaten with "land" and even "severe" level in the provinces of Almeria, Murcia and Alicante. In these provinces maximum values of elevation above $1 \mathrm{~m}$ are obtained offshore areas of top tourism economic interest, such as Torrevieja and Benidorm, with about 100000 and 70000 people, respectively (Figs. 3 and 10). These localities could present run-up heights of above $2 \mathrm{~m}$.

In general, all the Balearic islands are threatened by "land" or "severe" risk by all the sources of Northern Algeria (except the new source S-0 to the Eastern islands). These sources may pose significant threats to the islands of Ibiza and Minorca, with maximum wave elevations greater than $2 \mathrm{~m}$ (locally even higher than $4 \mathrm{~m}$ ). These elevations could result in run-up values above $4 \mathrm{~m}$. The North-East edge of the island of Ibiza and the South-East of Minorca, especially the bay of Mahón, present a clear tendency to exhibit local maximum elevations, making these areas and their populations particularly vulnerable.

In addition to the intrinsic wave elevation due to the tsunami, resonant effects have been demonstrated in the

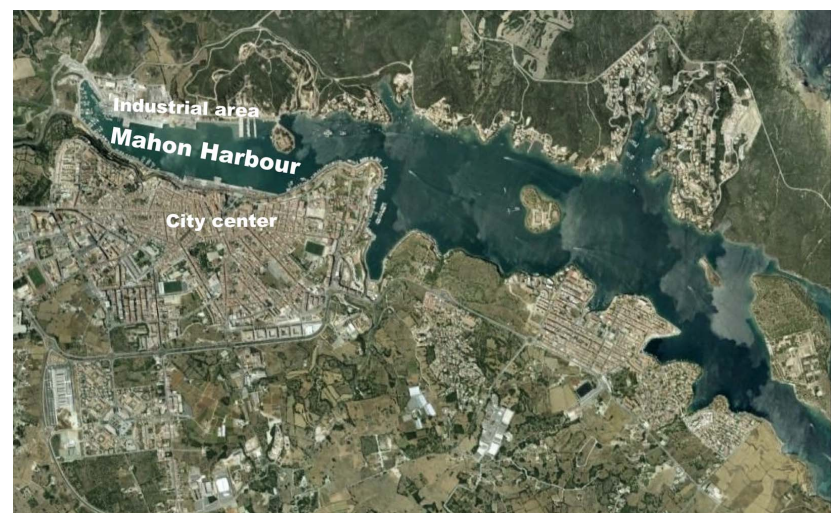

Fig. 11. Satellite image of the Mahón port, main commercial port and tourism center of Minorca.

Palma de Majorca Harbour and Mahón during the 2003 Zemmouri tsunami. In the Palma de Majorca Harbour no resonance appears to be associated with the harbour itself. The wave amplification inside the harbour, mainly in the Northern area, was generated by a resonance effect induced by the Palma bay. This corresponds with the reported damage zone by the Harbour Authority, as demonstrated by Vela et al. (2010). A similar resonant situation occurred in the Mahón harbour (TRANSFER, 2009) induced by the local geometry configuration (see Fig. 11).

\section{Conclusions}

The tsunamigenic sources used, although they always involve a simplification of the actual sources, allow the analysis of the regional tsunami hazard considering a wide range of scenarios. The sources S- $0, \mathrm{~S}-1$ and S-2 are the most dangerous because they greatly affect the islands of Ibiza and Formentera, as well as the peninsular coast. In general, the Northern Algerian sources pose a greater risk to the Spanish coast than the Alboran Sea sources.

From the elevation maps produced, as a first approximation, the areas of the Spanish Mediterranean margin particularly vulnerable to tsunamis can be estimated, as well as the sources that would pose a higher risk for the region also taking into account the tsunami travel times.

In the Iberian Peninsula the province of Murcia is the one that can be affected by greater tsunamis. These tsunamis would be generated in Northern Algeria, affecting the provinces of Almeria and Alicante, and especially the islands of Ibiza and Formentera.

The province of Almeria is at a high risk of being affected by a tsunami because it can be reached by virtually all sources of the Alboran Sea and the North West of Algeria, although with a low threat level. 
The provinces most likely to be affected by sources of the Alboran Sea are Malaga and Granada. The sources of the Alboran Sea with a higher risk of generating tsunamis are those in the Alboran Ridge. The generated tsunamis would take less than $30 \mathrm{~min}$ to reach the coast. The Carboneras and Yusuf faults do not have a high potential for tsunami generation, but due to its proximity to the coast could generate major submarine landslides, giving way to local tsunamis.

The Balearic Islands would not be affected by tsunamis generated in the Alboran Sea, however, all sources of Northern Algeria generate "land" or "severe" threats to all the islands, with tsunami travel times ranging from 30 to $45 \mathrm{~min}$. On the islands of Ibiza and Minorca are also recorded the highest maximum elevations, with heights that may pass the four-metre mark locally.

The results obtained in this work, and presented as a summary in Table 2, are a particularly useful tool for planning future regional and local warning systems, as well as to set research priority on detailed tsunami risk depending on the degree of threat presented. It would be of particular interest to conduct detailed research in the Balearic Islands and the South-Eastern margin of the Iberian Peninsula.

Acknowledgements. Thanks to Stefano Tinti who encouraged us to summarize our results from the European project TRANSFER (6.3.IV.2.2-037058) in the Western Mediterranean. We would also like to thank the editor S. Monserrat for his efficiency, and the suggestions and comments of G. Papadopoulos and an anonymous reviewer. The mapping software GMT (Wessel and Smith, 1998) has been used to produce the figures. JAAG acknowledges the funding of the projects TRANSFER (6.3.IV.2.2-037058) and ERTES-I (AECID, 09-CAP1-0161).

Edited by: S. Monserrat

Reviewed by: G. Papadopoulos and another anonymous referee

\section{References}

Alasset, P. J., Hébert, H., Maouche, S., Calbini, V., and Meghraoui, M.: The tsunami induced by the 2003 Zemmouri earthquake (MW $=6.9$, Algeria): modelling and results, Geophys. J. Int., 166, 213-226, 2006.

Allen, S. and Greenslade, D.: Developing tsunami warnings from numerical model output, Natural Hazards, 46, 35-52, doi:10.1007/s11069-007-9180-8, 2008.

Álvarez-Gómez, J. A., Aniel-Quiroga, Í., González, M., Olabarrieta, M., and Carreño, E.: Scenarios for earthquake-generated tsunamis on the Alboran Sea, Western Mediterranean, Mar. Geol., submitted, 2010a.

Álvarez-Gómez, J. A., Olabarrieta, M., González, M., Otero, L., Carreño, E., and Martínez-Solares, J. M.: The impact of tsunamis on the Island of Majorca induced by North Algerian seismic sources, Turk. J. Earth Sci., 19, 367-383, 2010 b.

Álvarez-Marrón, J.: Pliocene to Holocene structure of the eastern Alboran Sea (Western Mediterranean), in: Proceedings of the ODP, Scientific Results, edited by: Zahn, R., Comas, M. C., and Klaus, A., 161, 345-355, 1999.
Bezzeghoud, M., Dimitrov, D., Ruegg, J. C., and Lammali, K.: Faulting mechanism of the El Asnam (Algeria) 1954 and 1980 earthquakes from modelling of vertical movements, Tectonophysics, 249, 249-266, 1995.

Booth-Rea, G., Azañón, J. M., Azor, A., and García-Dueñas, V.: Influence of strike-slip fault segmentation on drainage evolution and topography. A case study: the Palomares Fault Zone (southeastern Betics, Spain), J. Struct. Geol., 26, 1615-1632, 2004.

Bourgois, J., Mauffret, A., Ammar, N. A., and Demnati, N. A.: Multichannel seismic data imaging of inversion tectonics of the Alboran Ridge (Western Mediterranean Sea), Geo-Mar. Lett., 12, 117-122, 1992.

Brizuela, B., Pagnoni, G., Tonini, R., and Tinti, S.: Assessment of Tsunami Hazard in Central America, Geophys. Res. Abstr., 11, EGU2009-2376, 2009.

Comas, M. C., García-Dueñas, V., and Jurado, M. J.: Neogene tectonic evolution of the Alboran Basin from MCS data, Geo-Mar. Lett., 12, 157-164, 1992.

DeMets, C., Gordon, R., Argus, D. F., and Stein, S.: Current plate motions, Geophys. J. Int., 101, 425-478, 1990.

Fernández-Ibáñez, F., Soto, J. I., Zoback, M. D., and Morales, J.: Present-day stress field in the Gibraltar Arc (western Mediterranean), J. Geophys. Res., 112, B08404, doi:10.1029/2006JB004683, 2007.

GEBCO: The GEBCO_08 Grid, version 20081212; http://www. gebco.net, 2008.

Gjevik, B. and Pedersen, G.: Run-up of long waves on an inclined plane, vol. 2 of Preprint series, Dept of Maths, University of Oslo, 25 pp., 1981.

Gràcia, E., Pallàs, R., Soto, J. I., Comas, M., Moreno, X., Masana, E., Santanach, P., Diez, E., García, M., and Dañobeitia, J.: Active faulting offshore SE Spain (Alboran Sea): Implications for earthquake hazard assessment in the Southern Iberian Margin, Earth Planet. Sci. Lett., 241, 734-749, 2006.

Hartzell, S. and Liu, P.: Calculation of earthquake rupture histories using a hybrid global search algorithm: application to the 1992 Landers, California, earthquake, Phys. Earth Planet. In., 95, 79_ 99, 1996.

IGN: Catálogo de Tsunamis en las Costas Españolas. Instituto Geográfico Nacional, www.ign.es, 2009.

Larouzière, F. D., de Bolze, J., Bordet, P., Hernández, J., Montenat, C., and Ott d'Estevou, P.: The Betic segment of the lithospheric Trans-Alboran shear zone during the Late Miocene, Tectonophysics, 152, 41-52, 1988.

Liu, P. L. F., Cho, S., Yoon, S. B., and Seo, S. N.: Numerical simulations of the 1960 Chilean tsunami propagation and inundation at Hilo, Hawaii, Recent Development in Tsunami Research, in: Tsunami: progress in prediction, disaster prevention and warning, edited by: Tsuchiya, Y. and Shutō, N., Adv. Nat. Technol. Haz., 99-115, Springer, 1994.

Liu, P. L.-F., Cho, Y.-S., Briggs, M. J., Kanoglu, U., and Synolakis, C. E.: Runup of solitary waves on a circular island, J. Fluid Mech., 302, 259-285, 1995.

Luis, J. F.: Mirone: A multi-purpose tool for exploring grid data, Comput. Geosci., 33, 31-41, 2007.

Martínez-Díaz, J. J.: Stress field variation related to fault interaction in a reverse oblique-slip fault: the Alhama de Murcia fault, Betic Cordillera, Spain, Tectonophysics, 356, 291-305, 2002.

Masana, E., Martínez-Díaz, J. J., Hernández-Enrile, J. L., and 
Santanach, P.: The Alhama de Murcia fault (SE Spain), a seismogenic fault in a diffuse plate boundary: Seismotectonic implications for the Ibero-Magrebian region, J. Geophys. Res., 109, B01301, doi:10.1029/2002JB002359, 2004.

McClusky, S., Reilinger, R., Mahmoud, S., Ben Sari, D., and Tealeb, A.: GPS constraints on Africa (Nubia) and Arabia plate motions, Geophys. J. Int., 155, 126-138, 2003.

Meghraoui, M. and Doumaz, F.: Earthquake-induced flooding and paleoseismicity of the El Asnam (Algeria) fault-related fold, J. Geophys. Res., 101, 17617-17644, 1996.

Morel, J. and Meghraoui, M.: Gorringe-Alboran-Tell tectonic zone: a transpression system along the Africa-Eurasia plate boundary, Geology, 24, 755-758, 1996.

Okada, Y.: Surface deformation due to shear and tensile faults in a half-space, B. Seismol. Soc. Am., 75, 1135-1154, 1985.

Papadopoulos, G. and Fokaefs, A.: Strong tsunamis in the Mediterranean Sea: A re-evaluation, ISET Journal of Earthquake Technology, 42, 159-170, 2005.

Reicherter, K. and Hübscher, C.: Evidence for a seafloor rupture of the Carboneras Fault Zone (southern Spain): Relation to the 1522 Almería earthquake?, J. Seismol., 11, 15-26, 2007.

Roger, J. and Hébert, H.: The 1856 Djijelli (Algeria) earthquake and tsunami: source parameters and implications for tsunami hazard in the Balearic Islands, Nat. Hazards Earth Syst. Sci., 8, 721-731, doi:10.5194/nhess-8-721-2008, 2008.

Sekiguchi, H. and Iwata, T.: Rupture Process of the 1999 Kocaeli, Turkey, Earthquake Estimated from Strong-Motion Waveforms, B. Seismol. Soc. Am., 92, 300-311, 2002.

Serpelloni, E., Vannucci, G., Pondrelli, S., Argnani, A., Casula, G., Anzidei, M., Baldi, P., and Gasperini, P.: Kinematics of the Western Africa-Eurasia plate boundary from focal mechanisms and GPS data, Geophys. J. Int., 169, 1180-1200, 2007.

Shokin, Y. I., Chubarov, L. B., Novikov, V. A., and Sudakov, A. N.: Calculations of tsunami travel time charts in the Pacific Ocean. Models, algorithms, techniques, results, Science of Tsunami Hazards, 5, 85-113, 1987.

Synolakis, C. E.: The runup of solitary waves, J. Fluid Mech., 185, 523-545, 1987.
Tiberti, M. M., Lorito, S., Basili, R., Kastelic, V., Piatanesi, A., and Valensise, G.: Scenarios of earthquake-generated tsunamis for the Italian coast of the Adriatic Sea, Pure Appl. Geophys., 165, 2117-2142, 2008.

TRANSFER: Tsunami scenarios for the Balearic Islands with focus on Palma de Mallorca and flooding maps of Palma de Mallorca, Tech. Rep. D8.3, EU Project no. 037058, 2009.

Umutlu, N., Koketsu, K., and Milkereit, C.: The rupture process during the 1999 Dqzce, Turkey, earthquake from joint inversion of teleseismic and strong-motion data, Tectonophysics, 391, 315-324, 2004.

Vela, J., Pérez, B., González, M., Otero, L., Olabarrieta, M., Canals, M., and Casamor, J. L.: Tsunami resonance in the Palma de Majorca bay and harbour induced by the 2003 BoumerdesZemmouri algerian earthquake (Western Mediterranean), in: Proceedings of 32nd International Conference on Coastal Engineering (ICCE 2010), ASCE, 2010.

Wang, X. and Liu, P. L.-F.: A Numerical investigation of Boumerdes-Zemmouri (Algeria) Earthquake and Tsunami, Comp. Model Eng., 10, 171-184, 2005.

Wang, X. and Liu, P. L.-F.: An analysis of 2004 Sumatra earthquake fault plane mechanisms and Indian Ocean tsunami, J. Hydraul. Res., 44, 147-154, 2006.

Watts, A. B., Platt, J. P., and Buhl, P.: Tectonic evolution of the Alboran Sea Basin, Basin Res., 5, 153-157, 1993.

Wessel, P. and Smith, W. H. F.: New improved version of Generic Mapping Tools released, EOS Transactions of the American Geophysical Union, 79, 579, 1998.

Woodside, J. and Maldonado, A.: Styles of compressional neotectonics in the Eastern Alboran Sea, Geo-Mar. Lett., 12, 111-116, 1992.

Yelles-Chaouche, A. K., Djellit, H., and Hamdache, M.: The Boumerdes-Algiers (Algeria) Earthquake of May 21st, 2003 (Mw=6.8), CSEM-EMSC newsletter, 20, 3-5, 2003.

Young, C. J., Lay, T., and Lynnes, C. S.: Rupture of the 4 February 1976 guatemalan earthquake, B. Seismol. Soc. Am., 79, 670689, 1989. 